\title{
Heavy Metals in Soils and Plants around Industries in Agbara Industrial Estate, Ogun State, Nigeria
}

\author{
Franklin E. Odili*, Kelechi L. Njoku, Adetokunbo Soyoye \\ Environmental Biology Research Unit, Department of Cell Biology and Genetics, University of Lagos, Lagos, Nigeria \\ Email: ^franklineodili@gmail.com
}

How to cite this paper: Odili, F. E., Njoku, K. L., \& Soyoye, A. (2018). Heavy Metals in Soils and Plants around Industries in Agbara Industrial Estate, Ogun State, Nigeria. Journal of Geoscience and Environment Protection, 6, 61-69.

https://doi.org/10.4236/gep.2018.612004

Received: October 27, 2018

Accepted: December 7, 2018

Published: December 10, 2018

Copyright ( 92018 by authors and Scientific Research Publishing Inc. This work is licensed under the Creative Commons Attribution International License (CC BY 4.0).

http://creativecommons.org/licenses/by/4.0/

\begin{abstract}
Indiscriminate handling and disposal of industrial effluents into the environment represents one of the major sources of environmental pollution which invariably affect plants, animals and humans. This study assessed heavy metal concentration in soils and plants around industries in Agbara industrial estate, Ogun State, Nigeria. Soil and plant samples were collected from four industries and analyzed for lead $(\mathrm{Pb})$, cadmium $(\mathrm{Cd})$, copper $(\mathrm{Cu})$, chromium $(\mathrm{Cr})$ and nickel $(\mathrm{Ni})$. The $\mathrm{pH}$, organic matter content and cation exchange capacity of the soil samples, as well as bioaccumulation factor (BAF) and translocation factor (TF) of the plant samples were examined. The heavy metal concentration order of the soil and plant samples was $\mathrm{Pb}<\mathrm{Cu}<$ $\mathrm{Cd}<\mathrm{Cr}<\mathrm{Ni} . \mathrm{Pb}, \mathrm{Cu}, \mathrm{Cr}$, and $\mathrm{Ni}$ in all soil samples were below WHO tolerance limit (300 mg kg${ }^{-1}, 50 \mathrm{mg} \mathrm{kg}^{-1}, 10 \mathrm{mg} \mathrm{kg}^{-1}$ and $50 \mathrm{mg} \mathrm{kg}^{-1}$ respectively) while $\mathrm{Cd}$ was above $\mathrm{WHO}$ tolerance limit $\left(3 \mathrm{mg} \mathrm{kg}^{-1}\right)$. Also, $\mathrm{Pb}, \mathrm{Cd}, \mathrm{Cu}$, and $\mathrm{Cr}$ in most plant samples were above WHO tolerance limits $\left(10 \mathrm{mg} \mathrm{kg}^{-1}, 0.30\right.$ $\mathrm{mg} \mathrm{kg}{ }^{-1}, 10 \mathrm{mg} \mathrm{kg}^{-1}$ and $1.5 \mathrm{mg} \mathrm{kg}^{-1}$ respectively). Statistical differences $(P<$ 0.01 ) were observed between heavy metals in soil and some plants. Furthermore, there was no correlation between heavy metals in soil and plants. The BAF and TF results showed that Cyperus iria, Alternanthera sessilis, C. esculentus, A. brasiliana, and Megathyrsus maximus are probable accumulators of heavy metals.
\end{abstract}

\section{Keywords}

Environment, Pollution, Heavy Metals, Industries, Bioaccumulators

\section{Introduction}

The increasing rate of industrialization, technological development, and so- 
cio-economic growth has led to the rapid expansion of the industrial sector in developing countries (Ayeni, 2013). The activities of human society influence biogeochemical cycles via industries and have led to various irreversible changes in our environment (Omar \& Al-Khashman, 2004). As a result, undesirable effects of poor environmental circumstances on human health are mostly manifested in the environment, predominantly in developing countries where urbanization, industrialization and rapid population growth are taking place on an unprecedented scale. The irregular disposal of industrial wastes has created pollution problems since this waste is dispersed in the environment and accumulated in sediments, aquatic organisms, and water (Ogwuegbu \& Muhanga, 2005). Majority of manufacturing processes are water based and a considerable volume of effluent is ejected to the environment in either treated or inadequately treated form, leading to soil and groundwater pollution (Lenntech, 2004). Prolonged exposure of man to toxic heavy metals in the cities has been reported by many researchers. Heavy metals such as arsenic, mercury, iron, nickel, lead, zinc, copper, and cadmium are prominent components of industrial effluents (Hawkes, 1997). Heavy metals have become increasingly significant within the framework of environmental pollution investigation. They are of serious concern as a result of their persistence in the environment and their carcinogenicity to human beings (Hawkes, 1997). Therefore, this research aimed to evaluate heavy metal concentration of soils and plants around industries located at Agbara industrial estate, Agbara, Ogun State, Nigeria.

\section{Materials and Methods}

\subsection{Study Area}

This study was conducted in Agbara industrial estate, Ogun State, Nigeria in June 2015. Agbara industrial estate is located in Agbara, Ogun State, Nigeria. It lies between latitude $6^{\circ} 15^{\prime} \mathrm{N}$ and $6^{\circ} 35^{\prime} \mathrm{N}$ and longitude $3^{\circ} 00^{\prime} \mathrm{E}$ and $3^{\circ} 15^{\prime} \mathrm{E}$, approximately 31 kilometers at the west side of Lagos on the Lagos-Badagry Expressway, Southwestern Nigeria (see Figure 1).

Soil and plant samples were collected at randomly selected industries located within the study area. 12 plants and 7 soil samples were collected at points of effluent discharge from Beloxxi Industries Ltd., Nestle Nigeria Plc., Avanti Industries Ltd and Beta Glass Plc. The plant samples were carefully removed from the soil, wrapped using newspapers and placed in large-sized brown envelopes, while soil samples were collected using soil auger, and then placed in black polythene bags. The plant samples were taken to the Department of Botany Herbarium, University of Lagos for identification. The plant species were identified based on their physical features, including leaves structure, leaves arrangement on the stem, and flower types. The identified plant species include Cyperus iria, Alternanthera sessilis, A. brasiliana, Asystasia gangetica, Aspilia africana, C. esculentus, Megathyrsus maximus, and Ludwigia perennis. 


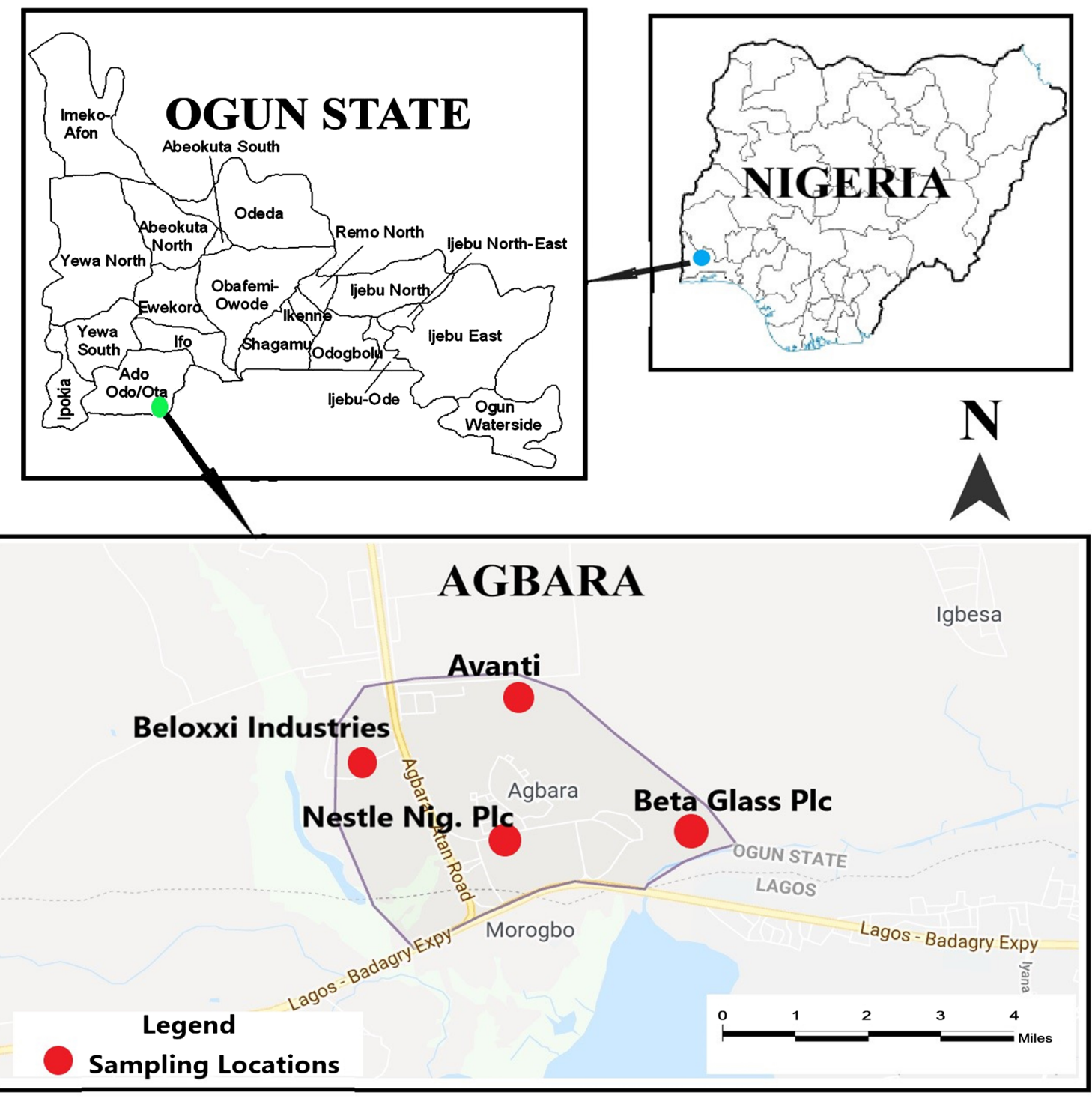

Figure 1. Map showing study area and sampling locations.

\subsection{Sample Preparation}

Sample preparation was performed following procedures described by Fakayode and Onianwa (2002). The plant samples were carefully separated into root and shoot and then air-dried along with the soil samples for a week. After drying, the samples were weighed to obtain $5 \mathrm{~g}$ which was taken to the laboratory for analysis.

\subsection{Laboratory Analysis}

The soil $\mathrm{pH}$ was measured using a glass electrode $\mathrm{pH}$ meter. A small portion of the sample was ignited by muffle for 4 hours at $550^{\circ} \mathrm{C}$. The losses during bakeout and ignition were determined separately as indirect index of organic matter content (OMC) (Sizmur et al., 2011). For the cation exchange capacity (CEC) and heavy metal detection, $0.1 \mathrm{~g}$ samples were picked by a high precision analyt- 
ical balance. Subsequently, the samples were placed in Teflon tubes and digested with $\mathrm{HNO}_{3}, \mathrm{HF}$, and $\mathrm{HClO}_{4}$. Then the solutions were diluted with $2 \%(\mathrm{v} / \mathrm{v})$ $\mathrm{HNO}_{3}$ to a final volume of $50 \mathrm{~mL}$, and analyzed for $\mathrm{Cd}, \mathrm{Cu}, \mathrm{Zn}, \mathrm{Pb}$ by an atomic absorption spectrophotometer: AAnalyst 200, Perkin-Elmer Inc, US (Nemati et al., 2009).

The bioaccumulation factor $(B A F)$ of heavy metals in the plant samples was determined by calculating the ratio of heavy metal concentration in the plant root to that of the soil as given below:

$$
B A F=C_{p r} / C_{s}
$$

where $C_{p r}$ and $C_{s}$ are heavy metal concentrations $\left(\mathrm{mg} \mathrm{kg}^{-1}\right)$ in plant root and soil respectively. BAF values were used to identify plant species that were hyperaccumulators $\left(>10 \mathrm{mg} \mathrm{kg}^{-1}\right)$, accumulators $\left(>1 \mathrm{mg} \mathrm{kg}^{-1}\right)$ and excluders $(<1 \mathrm{mg}$ $\mathrm{kg}^{-1}$ ) (Ma et al., 2001).

The ability of the plant samples to translocate heavy metals from root to shoot was determined by calculating the translocation factor $(T F)$ which is given below:

$$
T F=C_{p s} / C_{p r}
$$

where $C_{s}$ and $C_{r}$ are heavy metal concentrations $\left(\mathrm{mg} \mathrm{kg}^{-1}\right)$ in plant root and plant shoot respectively. TF values $\left(>1 \mathrm{mg} \mathrm{kg}^{-1}\right)$ indicate that the plant can translocate heavy metals effectively from root to shoot (Baker \& Brooks, 1989).

\subsection{Statistical Analysis}

The results from the laboratory analysis were subjected to Pearson correlation and analysis of variance (two-way ANOVA) at 95\% confidence level using Microsoft Excel 2010 and Graphpad prism version 6.0.

\section{Results}

\subsection{Heavy Metal Concentration in Soil and Plant Samples}

The concentrations of heavy metals in soil and plant samples are shown in Table 1

Table 1. Heavy metal concentration in soil samples.

\begin{tabular}{ccccccc}
\hline INDUSTRY & $\begin{array}{c}\text { SAMPLING } \\
\text { POINTS }\end{array}$ & $\begin{array}{c}\mathrm{Pb} \\
\left(\mathrm{mg} \mathrm{kg}^{-1}\right)\end{array}$ & $\begin{array}{c}\mathrm{Cd} \\
\left(\mathrm{mg} \mathrm{kg}^{-1}\right)\end{array}$ & $\begin{array}{c}\mathrm{Cu} \\
\left(\mathrm{mg} \mathrm{kg}^{-1}\right)\end{array}$ & $\begin{array}{c}\mathrm{Cr} \\
\left(\mathrm{mg} \mathrm{kg}^{-1}\right)\end{array}$ & $\begin{array}{c}\mathrm{Ni} \\
\left(\mathrm{mg} \mathrm{kg}^{-1}\right)\end{array}$ \\
\hline \multirow{2}{*}{ BELOXXI } & POINT 1 & 13.85 & 1.75 & 12.60 & 4.76 & 0.20 \\
& POINT 2 & $\mathrm{ND}$ & 10.45 & 8.65 & $\mathrm{ND}$ & 0.30 \\
\multirow{2}{*}{ NESTLE } & POINT 1 & ND & 5.20 & 4.10 & $\mathrm{ND}$ & 0.11 \\
\multirow{2}{*}{ AVANTI } & POINT 2 & 42.35 & 4.80 & 10.20 & $\mathrm{ND}$ & 0.20 \\
\multirow{2}{*}{ BETA GLASS } & POINT 1 & ND & 4.95 & 3.05 & 12.80 & 0.41 \\
& POINT 1 & 15.15 & 5.70 & 24.90 & 4.82 & 0.29 \\
\multirow{2}{*}{ WHO Standard Tolerance Limit } & 300 & 3.00 & 50 & 100 & 50
\end{tabular}

ND: Not Detected. 
and Figure 2. The average relative order of heavy metals in the soil and plant samples was $\mathrm{Pb}<\mathrm{Cu}<\mathrm{Cd}<\mathrm{Cr}<\mathrm{Ni}$. Cd, $\mathrm{Cu}$, and $\mathrm{Ni}$ were present in all soil and plant samples while $\mathrm{Pb}$ and $\mathrm{Cr}$ were mostly not detected. The levels of $\mathrm{Pb}, \mathrm{Cu}, \mathrm{Cr}$ and $\mathrm{Ni}$ in all the soil samples were below WHO tolerance limits $\left(300 \mathrm{mg} \mathrm{kg}^{-1}, 50\right.$ $\mathrm{mg} \mathrm{kg}^{-1}, 100 \mathrm{mg} \mathrm{kg}^{-1}$ and $50 \mathrm{mg} \mathrm{kg}^{-1}$ respectively) while Cd level in all the soil samples (except for Beloxxi point 1) were above WHO standard tolerance limit ( $3 \mathrm{mg} \mathrm{kg}^{-1}$ ). The levels of $\mathrm{Pb}, \mathrm{Cd}, \mathrm{Cu}$, and $\mathrm{Cr}$ detected in the plant samples (both root and shoot) were above their respective WHO standard tolerance limits (10 $\mathrm{mg} \mathrm{kg}$, $0.30 \mathrm{mg} \mathrm{kg}-10 \mathrm{mg} \mathrm{kg}^{-1}$ and $1.5 \mathrm{mg} \mathrm{kg}^{-1}$ respectively) except for $\mathrm{Ni}$ whose level in all the plant samples were below WHO standard tolerance limit $\left(1.5 \mathrm{mg} \mathrm{kg}^{-1}\right)$. Statistical analysis showed a significant difference $(\mathrm{P}<0.01)$ between the level of $\mathrm{Pb}, \mathrm{Cd}, \mathrm{Cu}, \mathrm{Cr}$ and $\mathrm{Ni}$ in the soil samples from all sampling points when compared to WHO standard tolerance limits. Furthermore, the concentration of $\mathrm{Pb}, \mathrm{Cd}, \mathrm{Cu}, \mathrm{Cr}$ and $\mathrm{Ni}$ in the plant samples were also significantly different $(\mathrm{P}<0.01)$. There was no (zero) correlation between the heavy metals in soil and in plants.

\subsection{Bioaccumulation Factor (BAF) and Translocation Factor (TF)}

Results for BAF and TF are shown in Figure 3 and Figure 4. BAF and TF values for $\mathrm{Pb}$ and $\mathrm{Cr}$ in almost all the plant samples could not be obtained because $\mathrm{Pb}$ and $\mathrm{Cr}$ were not detected either the soil or the plant root/shoot. The BAF values for $\mathrm{Cd}$ and $\mathrm{Cu}$ in most of the plant samples was greater than $1(>1)$, the maximum value recorded was $6.14(\mathrm{Cd})$ in $\mathrm{BP} 1 \mathrm{~b}$ and $3.56(\mathrm{Cu})$ in $\mathrm{BGP} 2 \mathrm{~b}$. The TF value for $\mathrm{Cd}$ in the plant samples was mostly greater than $1(>1)$ with NP1 having the highest value of 3.38, while the TF for $\mathrm{Cu}$ were mostly less than $1(<1)$ with AV recording the highest value of 2.88. BAF value for $\mathrm{Cr}$ was mostly not calculated as earlier stated; nonetheless, BP1a recorded the maximum value of

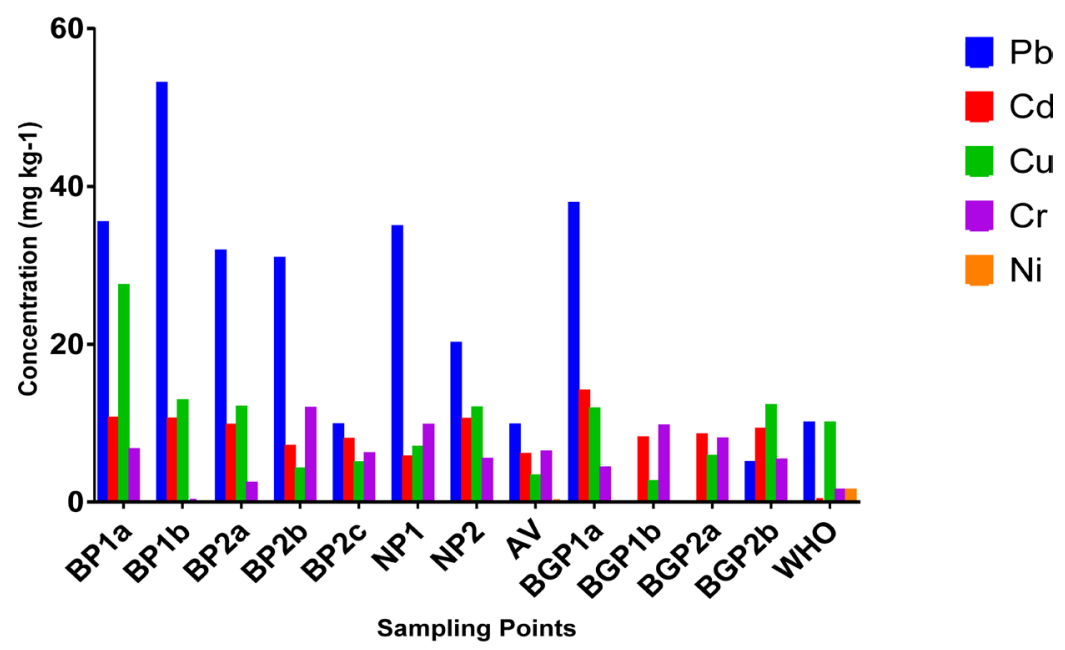

BP1a: Cyperus iria, BP1b: Alternanthera sessilis, BP2a: Asystasia gangetic, BP2b: A. brasiliana, BP2c: Aspilia africana, NP1: C. iria, NP2: A. sessilis, AV: A. brasiliana, BGP1a: C. esculentus, BG1Pb: $M e-$ gathyrsus maximus, BGP2a: C. iria, BGP2b: Ludwigia perennis

Figure 2. Heavy metals in plant samples. 


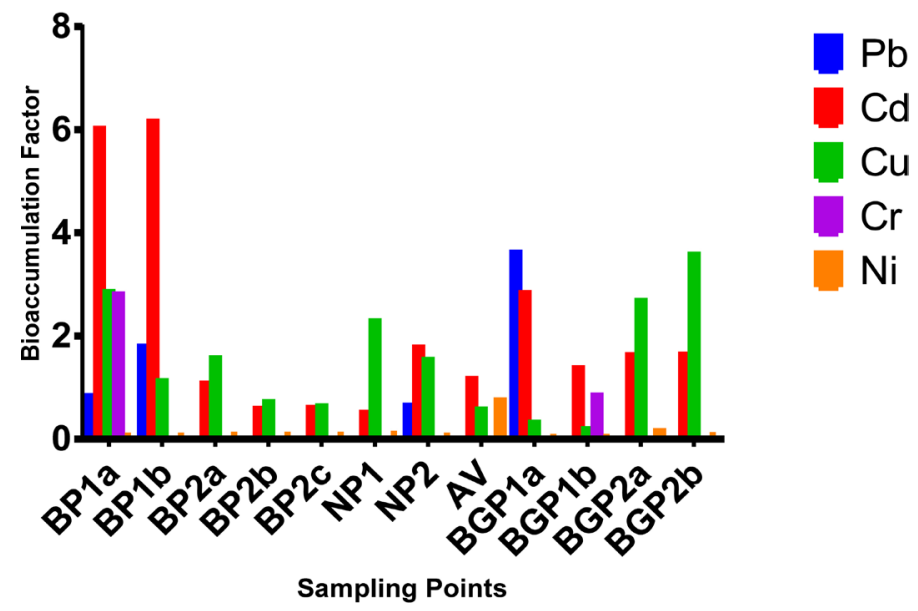

BP1a: Cyperus iria, BP1b: Alternanthera sessilis, BP2a: Asystasia gangetic, BP2b: A. brasiliana, BP2c: Aspilia africana, NP1: C. iria, NP2: A. sessilis, AV: A. brasiliana, BGP1a: C. esculentus, BG1Pb: Megathyrsus maximus, $\mathrm{BGP2a}$ : C. iria, $\mathrm{BGP} 2 \mathrm{~b}$ : Ludwigia perennis

Figure 3. Bioaccumulation factor in plant samples.

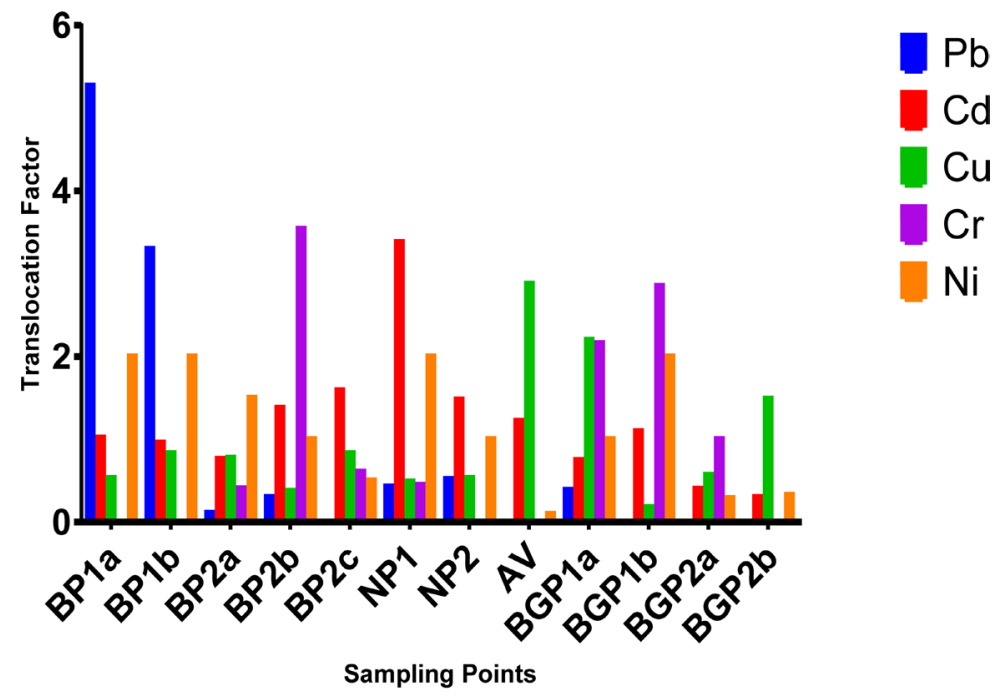

BP1a: Cyperus iria, BP1b: Alternanthera sessilis, BP2a: Asystasia gangetic, BP2b: A. brasiliana, BP2c: Aspilia africana, NP1: C. iria, NP2: A. sessilis, AV: A. brasiliana, BGP1a: C. esculentus, BG1Pb: Megathyrsus maximus, BGP2a: C. iria, BGP2b: Ludwigia perennis

Figure 4. Translocation factor in plant samples.

2.79, while BP2c recorded the highest value of 3.54 for TF in Cr. BAF values for $\mathrm{Ni}$ were less than $1(<1)$ with AV recording the maximum value while the TF values for Ni were mostly greater than $1(<1)$; BP1a, BP1b, NP1, and BGP1b all recorded TF values of 2.00 .

Statistical analysis showed that there was a significant difference $(\mathrm{P}<0.01)$ between the BAF values of $\mathrm{Cd}$ and $\mathrm{Ni}$ in $\mathrm{BP} 1 \mathrm{a}, \mathrm{Cd}$, and $\mathrm{Cu}, \mathrm{Cr}$, and $\mathrm{Ni}$ in $\mathrm{BP} 1 \mathrm{~b}$. Also, there was a significant difference $(\mathrm{P}<0.01)$ between the $\mathrm{BAF}$ values of $\mathrm{Cd}$ in BP1a and BP1b, BP1a and BP2c, and BP1a and NP1. There was also a statistical difference $(\mathrm{P}<0.0001)$ between the TF values of $\mathrm{Pb}$ and $\mathrm{Cu}, \mathrm{Pb}$ and $\mathrm{Cr}$ in BP1a. 


\subsection{Soil pH, Organic Matter Content (OMC) and Cation Exchange Capacity (CEC)}

The $\mathrm{pH}, \mathrm{OMC}$, and CEC of the sampled soils are shown in Figure 5. The $\mathrm{pH}$ values were neutral and ranged from 6.46 to 7.53, with Avanti and Beloxxi point 2 recording the highest and the lowest $\mathrm{pH}$ values respectively. The organic matter content values were all greater than $2 \%$ and it ranged from $2.88 \%$ (Avanti) to $4.10 \%$ (Beta Glass point 2), while the cation exchange capacity values ranged from 1.08 to $2.41 \mathrm{mg} \mathrm{kg}^{-1}$ with Avanti and Nestle point 2 recording the highest and the lowest values respectively. Statistical analysis showed that there was a significant difference $(\mathrm{p}<0.0001)$ between the $\mathrm{pH}$, organic matter content and cation exchange capacity of the soil in each of the sampling points (except for OMC and CEC from Avanti) when compared to each other.

\section{Discussion}

The hazardous effects of heavy metals on the biotic community of the ecosystem cannot be overemphasized as heavy metals are introduced into the environment through the discharge of industrial effluents (Ademoroti, 1996). Presence of $\mathrm{Pb}$, $\mathrm{Cu}, \mathrm{Cd}, \mathrm{Cr}$ and $\mathrm{Ni}$ in this study is usually as a result of the industrial activities, especially burning of fossil fuels during production processes (Ademoroti, 1996; Wang et al., 2009; Addo et al., 2012). High level of these metals in food crops grown around industrial areas have been attributed to several health issues, such as disruption of the biosynthesis of haemoglobin and anaemia, rise in blood pressure, kidney damage, miscarriages and subtle abortions, disruption of nervous response and brain cell, formation and increasing the incidence of cancer, and respiratory dysfunction (Lenntech, 2004; Fatoba et al., 2012).

$\mathrm{BAF}$ and TF can be used to estimate a plant's potential for phytoremediation (Ismail et al., 2007). The BAF and TF of most plants in this study revealed the accumulation of heavy metals from the soil and translocating them from the root to the shoot of the plants. BAF and TF values greater than 1 indicates that the

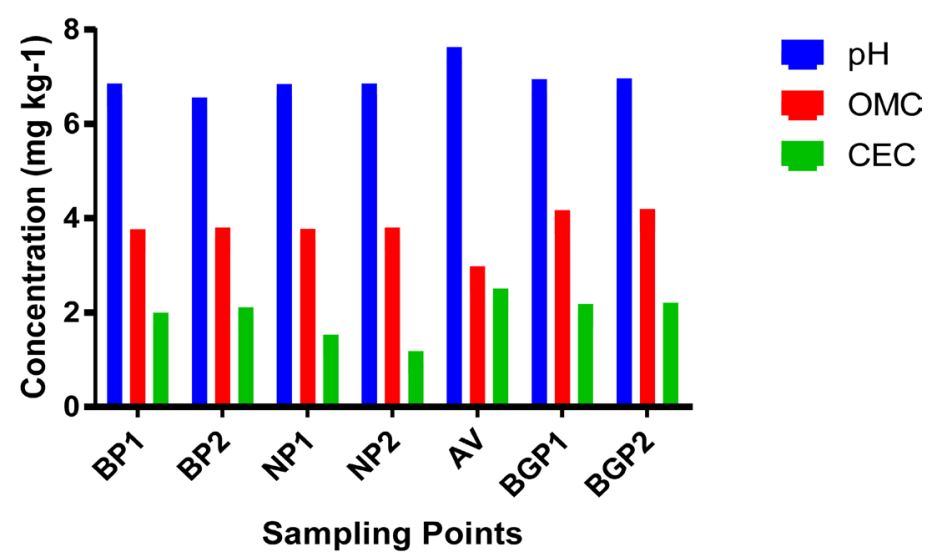

BP1: Beloxxi Point 1, BP2: Beloxxi Point 2, NP1: Nestle Point 1, NP2: Nestle Point 2, AV: Avanti, BGP1: Beta Glass Point 1, BGP2: Beta Glass Point 2

Figure 5. pH, organic matter content and cation exchange capacity of soil samples. 
plant is suitable for phytoextraction as a result of its ability to accumulate and translocate metal ions (Yoon et al., 2006). The BAF and TF values revealed that among the eight species of plants in this study, Cyperus iria, Alternanthera sessilis, C. esculentus, A. brasiliana, and Panicum maximum are probable accumulators as they all accumulated high amount of almost all the heavy metals. Accumulation of heavy metals in the plants than in the soil could be as a result of the plants' need to absorb soil nutrients and thus also taking up heavy metals in the process.

\section{Conclusion}

The high concentrations of toxic heavy metals in the soil and plant samples confirm pollution in the area. This is due to the indiscriminate disposal of untreated wastewater and the failure of the manufacturing industries to adhere to environmental protection guidelines. The discharge of untreated wastewaters into the natural environment may have also contributed significantly to the accumulation of heavy metals in the ecosystem. Therefore, it is important that the polluting industries treat wastewaters using state-of-the-art technologies before disposal in order to protect the environment and reduce potential health risks.

\section{Acknowledgements}

The authors are thankful to the staff of the Department of Botany herbarium, University of Lagos for their assistance in identifying the plant samples.

\section{Conflicts of Interest}

The authors declare no conflicts of interest regarding the publication of this paper.

\section{References}

Addo, M. A., Darko, E. O., Gordon, C., Nyarko, B. J. B., Gbadago, J. K., Nyarko, E., Affum, H. A., \& Botwe, B. O. (2012). Evaluation of Heavy Metals Contamination of Soil and Vegetation in the Vicinity of a Cement Factory in the Volta Region, Ghana. International Journal of Science and Technology, 2, 40-50.

Ademoroti, C. M. (1996). Standard Methods for Water and Effluent Analysis. Ibadan: Foludex Press.

Ayeni, O. (2013). Risk Assessment of Raw Effluents Discharged from an Industrial Estate in Lagos, Southwestern Nigeria. Greener Journal of Environmental Management and Public Safety, 2, 189-194. https://doi.org/10.15580/GJEMPS.2013.5.110113939

Baker, A. J. M., \& Brooks, R. R. (1989). Terrestrial Higher Plants Which Hyperaccumulate Metallic Elements-A Review of Their Distribution, Ecology, and Phytochemistry. Biorecovery, 1, 81-86.

Fakayode, S., \& Onianwa, P. (2002). Heavy Metal Contamination of Soil, and Bioaccumulation in Guinea Grass (Panicum maximum) around Ikeja Industrial Estate, Lagos, Nigeria. Environmental Geology, 43, 145-150. https://doi.org/10.1007/s00254-002-0633-9

Fatoba, P. O., Ogunkunle, C. O., \& Olawepo, G. K. (2012). Assessment of Atmospheric 
Metal Depositions in the Industrial Areas of the Southwest of Nigeria. Ethiopian Journal of Environmental Studies and Management, 5, 214-221.

https://doi.org/10.4314/ejesm.v5i3.7

Hawkes, J. S. (1997). Heavy Metals. Journal of Chemistry Education, 74, 1374. https://doi.org/10.1021/ed074p1374

Ismail, A. L., Dauda, M., \& Hassan, K. (2007). Environmental Pollution by Heavy Metals from Some Industrial Effluents at Sharada, Kano, Nigeria. Journal of Food, Agriculture, and Environment, 5, 315-317.

Lenntech, W. (2004). Water Treatment and Air Purification (54 p). Rotterdam: Lenntech.

Ma, L. Q., Komar, K. M., Tu, C., Zhang, W., Cai, Y., \& Kenelly, E. D. (2001). A Fern That Hyperaccumulates Arsenic. Nature, 409, 579-582. https://doi.org/10.1038/35054664

Nemati, K., Bakar, N. K. A., \& Abas, M. R. (2009). Investigation of Heavy Metals Mobility in Shrimp Aquaculture Sludge-Comparison of Two Sequential Extraction Procedures. Microchemical Journal, 91, 227-231. https://doi.org/10.1016/j.microc.2008.12.001

Ogwuegbu, M. O., \& Muhanga, W. (2005). Investigation of Lead Concentration in the Blood of People in the Copper Belt Province of Zambia. Journal of Environment, 11, 66-75.

Omar, A., \& Al-Khashman, B. (2004). Heavy Metal Distribution in Street Dust and Soils from the Workplace in Karak Industrial Estate, Jordan. Journal of Atmospheric Environment, 38, 6803-6812. https://doi.org/10.1016/j.atmosenv.2004.09.011

Sizmur, T., Palumbo-Roe, B., Watts, M. J., \& Hodson, M. E. (2011). Impact of the Earthworm Lumbricus terrestris (L.) on $\mathrm{As}, \mathrm{Cu}, \mathrm{Pb}$ and $\mathrm{Zn}$ Mobility and Speciation in Contaminated Soils. Environmental Pollution, 159, 742-748.

https://doi.org/10.1016/j.envpol.2010.11.033

Wang, Z. M., Song, K. S., Zhang, B., Liu, D. W., Li, X. Y., Ren, C. Y., Zhang, S, M., Luo, L., \& Zhang, C. H. (2009). Spatial Variability and Affecting Factors of Soil Nutrients in Crops Land of Northeast China. Soil and Plant, 55, 110-120. https://doi.org/10.17221/323-PSE

Yoon, J. X., Cao, Q., Zhou, Q., \& Ma, L. (2006). Accumulation of Pb, Cu, and $\mathrm{Zn}$ in Native Plants Growing on a Contaminated Florida Site. Science Total Environment, 368, 456-464. https://doi.org/10.1016/j.scitotenv.2006.01.016 